\title{
Harmful and beneficial aspects of Parthenium hysterophorus: an update
}

\author{
Seema Patel
}

Received: 27 September 2010/Accepted: 5 April 2011/Published online: 27 April 2011

(c) The Author(s) 2011. This article is published with open access at Springerlink.com

\begin{abstract}
Parthenium hysterophorus is a noxious weed in America, Asia, Africa and Australia. This weed is considered to be a cause of allergic respiratory problems, contact dermatitis, mutagenicity in human and livestock. Crop production is drastically reduced owing to its allelopathy. Also aggressive dominance of this weed threatens biodiversity. Eradication of $P$. hysterophorus by burning, chemical herbicides, eucalyptus oil and biological control by leaf-feeding beetle, stem-galling moth, stem-boring weevil and fungi have been carried out with variable degrees of success. Recently many innovative uses of this hitherto notorious plant have been discovered. Parthenium hysterophorus confers many health benefits, viz remedy for skin inflammation, rheumatic pain, diarrhoea, urinary tract infections, dysentery, malaria and neuralgia. Its prospect as nano-medicine is being carried out with some preliminary success so far. Removal of heavy metals and dye from the environment, eradication of aquatic weeds, use as substrate for commercial enzyme production, additives in cattle manure for biogas production, as biopesticide, as green manure and compost are to name a few of some other potentials. The active compounds responsible for hazardous properties have been summarized. The aim of this review article is to explore the problem $P$. hysterophorus poses as a weed, the effective control measures that can be implemented as well as to unravel the latent beneficial prospects of this weed.
\end{abstract}

S. Patel $(\square)$

Department of Biotechnology,

Lovely Professional University,

Jalandhar 144402, Punjab, India

e-mail: seemabiotech83@gmail.com
Keywords Parthenium hysterophorus .

Sesquiterpene lactone - Dermatitis - Biocontrol ·

Green manure $\cdot$ Bioremediation

\section{Introduction}

Parthenium hysterophorus is an aggressive ubiquitous annual herbaceous weed with no economic importance unravelled till now. This erect, ephemeral herb known for its vigorous growth and high fecundity especially in warmer climates is a native of north-east Mexico and is endemic in America. It is commonly known as 'altamisa', carrot grass, bitter weed, star weed, white top, wild feverfew, the "Scourge of India" and congress grass (Fig. 1a). Parthenium hysterophorus is a prolific weed belonging to Asteraceae family, producing thousands of small white capitula each yielding five seeds on reaching maturity. Within the past century it has found its way to Africa, Australia, Asia and Pacific Islands (Fig. 1b) and has now become one of the world's seven most devastating and hazardous weeds. This noxious weed is often spotted on abandoned lands, developing residential colonies around the towns, railway tracks, roads, drainage and irrigation canals, etc. This weed grows luxuriantly in established gardens, plantations and vegetable crops. Due to its high fecundity a single plant can produce 10,000 to 15,000 viable seeds and these seeds can disperse and germinate to cover large areas.

This alien weed is believed to have been introduced into India as contaminants in PL 480 wheat (Public Law 480 passed in 1954 to give food grains to developing countries for eliminating starvation and malnutrition) imported from the USA in the 1950s. Presently, this invasive weed is widely prevalent in India (Singh et al. 2008). Approximately two 
Fig. 1 a $P$. hysterophorus weed; b geographical distribution of $P$. hysterophorus
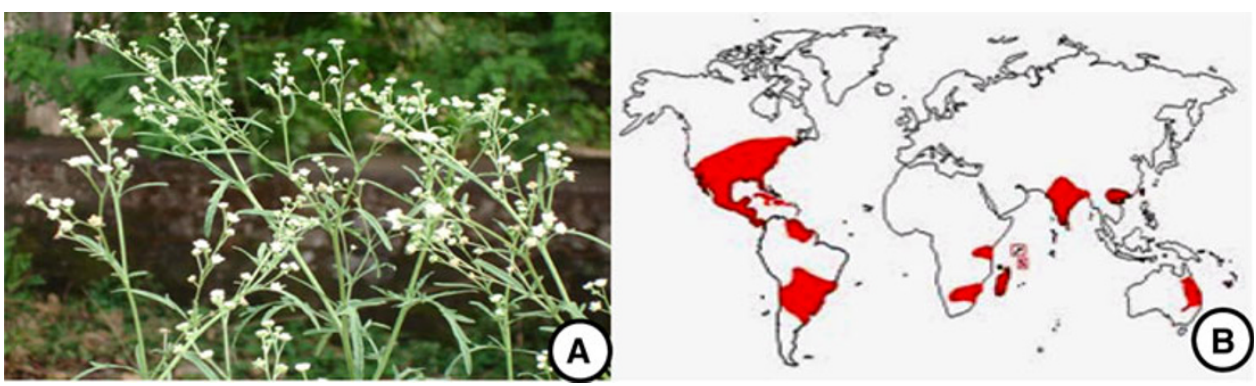

million hectares of land in India have been infested with this herbaceous menace (Dwivedi et al. 2009).

Looking at the multitude of harms caused by $P$. hysterophorus, its management is necessary to prevent future problems. Since $P$. hysterophorus grows luxuriantly in many parts of the world, it is important to explore its beneficial uses if any. The purpose of this review article is to summarize the published papers in this area and highlight the menacing roles of the weed.

\section{Chemical analysis of $\boldsymbol{P}$. hysterophorus}

Isolation and structural elucidation of the active principles of $P$. hysterophorus is required to determine their chemical properties. Chemical analysis of $P$. hysterophorus has indicated that all its parts including trichomes and pollen contain toxins called sesquiterpene lactones (SQL). Maishi et al. (1998) reported that $P$. hysterophorus contains a bitter glycoside parthenin, a major sesquiterpene lactone. Other phytotoxic compounds or allelochemicals are hysterin, ambrosin, flavonoids such as quercelagetin 3,7-dimethylether, 6-hydroxyl kaempferol 3-0 arabinoglucoside, fumaric acid. P-hydroxy benzoin and vanillic acid, caffeic acid, $p$ courmaric, anisic acid, p-anisic acid, chlorogenic acid, ferulic acid, sitosterol and some unidentified alcohols (Fig. 2). Parthenin, hymenin and ambrosin are found to be the culprits behind the menacing role of this weed in provoking health hazards (Lata et al. 2008). Parthenium hysterophorus from different geographical regions exhibited parthenin, hymenin, coronopilin, dihydroisoparthenin, hysterin, hysterophorin and tetraneurin $\mathrm{A}$ as the principal constituents of their sesquiterpene lactones (De La Fuente et al. 1997). Gupta et al. (1996) identified a novel hydroxyproline-rich glycoprotein as the major allergen in $P$. hysterophorus pollen. Das et al. (2007) examined the flowers of $P$. hysterophorus and isolated four acetylated pseudoguaianolides along with several known constituents. A novel sesquiterpenoid, charminarone, the first secopseudoguaianolide, has been isolated along with several known compounds from the whole plant by Venkataiah et al. (2003). Chhabra et al. (1999) discovered three ambrosanolides from the chloroform extract of this weed.

\section{Health hazards to humans and livestock}

This weed is known to cause many health hazards which have now reached epidemic proportions. Agriculturists are concerned about $P$. hysterophorus affecting food and fodder crops, since the pollen and dust of this weed elicit allergic contact dermatitis in humans (Gunaseelan 1987; Morin et al. 2009). Dermatitis is a T cell-mediated immune injury and the disease manifests as itchy erythematous papules and papulovesicular lesions on exposed areas of the body (Akhtar et al. 2010). These effects have been related to cytotoxicity of the sesquiterpene lactone parthenin (Narasimban et al. 1984). Persons exposed to this plant for prolonged period manifest the symptoms of skin inflammation, eczema, asthma, allergic rhinitis, hay fever, black spots, burning and blisters around eyes. Parthenium hysterophorus also causes diarrhoea, severe papular erythematous eruptions, breathlessness and choking (Maishi et al. 1998). Exposure to P. hysterophorus pollens causes allergic bronchitis (Towers and Subba Rao 1992). Ramos et al. (2001) assessed the mutagenic potential of a crude extract of $P$. hysterophorus in the Salmonella/microsome (Ames) assay and the mouse bone marrow micronucleus test. However, it did not show genotoxic potential. Sharma et al. (2005) observed that the clinical pattern of Parthenium dermatitis progresses from airborne contact dermatitis to mixed pattern or chronic actinic dermatitis pattern. Eczema herpeticum is reported to complicate parthenium dermatitis. Sriramarao et al. (1993) worked on the use of murine polyclonal anti-idiotypic antibodies as surrogate allergens in the diagnosis of $P$. hysterophorus hypersensitivity. Parthenium-sensitive patients with rhinitis who had positive results on skin prick tests to $P$. hysterophorus pollen extracts responded with a positive skin reaction to $m \mathrm{Ab}-2$. Akhtar et al. (2010) studied the involvement of $\mathrm{T}_{\mathrm{H}}$ type cytokines in Parthenium dermatitis.

Exposure to $P$. hysterophorus also causes systemic toxicity in livestock (Gunaseelan 1987). Alopecia, loss of skin pigmentation, dermatitis and diarrhoea has been reported in animals feeding on $P$. hysterophorus. Degenerative changes in both the liver and kidneys and inhibition of liver dehydrogenases have been reported in buffalo and sheep (Rajkumar et al. 1988). The milk and meat quality of 
Fig. 2 Sesquiterpene lactones from $P$. hysterophorus

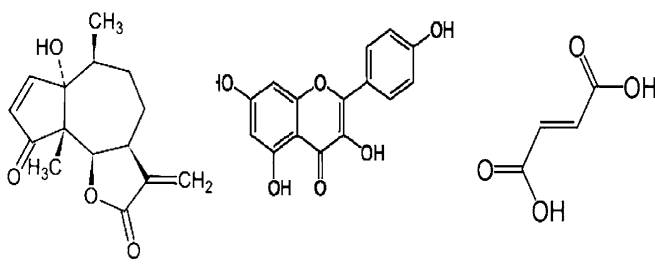

Parthenin
Quercelagetin
Fumaric acid<smiles>O=C(c1ccccc1)C(O)c1ccccc1</smiles>

P-hydroxybenzoin<smiles>COc1cc(C(=O)O)ccc1O</smiles>

Vanillic acid<smiles>O=C(O)/C=C/C(=C/C=C/O)/C=C/O</smiles>

Caffeic acid<smiles>O=C(O)/C=C/c1ccc(O)cc1</smiles>

P-coumaric acid

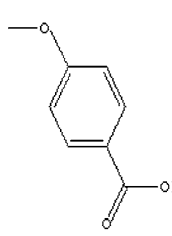

P-anisic acid

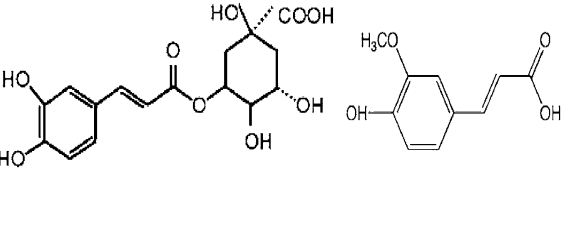

Chlorogenic acid

Ferulic acid cattle, buffalo and sheep deteriorate on consumption of this weed (Lakshmi and Srinivas 2007). Significant reduction in rat WBC count after oral treatment of Parthenium extract signifies its immune system weakening ability (Yadav et al. 2010).

\section{Reducing agricultural and pasture productivity}

Singh et al. (2003) explored the allelopathic properties of unburnt (UR) and burnt (BR) residues of P. hysterophorus on the growth of winter crops, radish and chickpeas. The extract prepared from both UR and BR was toxic to the seedling length and dry weight of the test crops. BR extract was more toxic due to its highly alkaline nature. Growth studies conducted in soil amended with UR and BR extracts revealed phytotoxic effects towards test crops, UR being more active than BR unlike crude extracts. These effects were attributed to the presence of phenolics (Singh et al. 2003). Parthenin leaching as root exudate plays a pivotal role in allelopathic interference with surrounding plants (Belz et al. 2007). Parthenin has also been reported as a germination and radicle growth inhibitor in a variety of dicot and monocot plants and it enters the soil through the decomposing leaf litter (Gunaseelan 1998). Burning of $P$. hysterophorus in fields reduced germination, biomass growth, plumule and radicle length of Phaseolus mungo (Kumar and Kumar 2010). Poor fruiting of leguminous crops and reduction in chlorophyll content of crop plants were observed in $P$. hysterophorus-infested fields (Lakshmi and Srinivas 2007). Parthenium hysterophorus played role as alternate host for crop pests functioning as an inoculum source. This weed has been reported to serve as a reservoir plant of scarab beetle, a pest of sunflower. Parthenium hysterophorus invasion causes changes in above-ground vegetation and below-ground soil nutrient contents, disturbing the entire grassland ecosystem in Nepal as reported by Timsina et al. (2010).

Parthenium hysterophorus is a serious invasive weed of pasture systems, reducing pasture productivity $90 \%$ (Evans 1997). It has become a major weed of grazing lands in central Queensland and New South Wales in Australia. It squeezes grasslands and pastures, reducing the fodder supply. Dhileepan (2007) observed dwindling effect of $P$. hysterophorus on grass biomass of grazing fields in Queensland, Australia.

\section{Biodiversity loss due to $P$. hysterophorus}

The invasive capacity and alleolopathic properties have rendered $P$. hysterophorus with the potential to disrupt the natural ecosystems. Very sparse or sometimes no other vegetation can be seen in $P$. hysterophorus-dominated areas. It has been reported to be causing a total habitat change in native Australian grasslands, open woodlands, river banks and flood plains (Lakshmi and Srinivas 2007). These weeds rapidly invade new surroundings often replace the indigenous species and pose a serious threat to biodiversity in India. Akter and Zuberi (2009) conducted an extensive survey on invasive alien species (IAS) and their impact on different land use types viz. road side, low land, fallow land, homestead and railway track in Bangladesh. Among others, P. hysterophorus exhibited the ability to invade and adapt to new habitats, thereby reducing the number of indigenous plants. The more vigorous mode of reproduction and the possession of an array of secondary metabolites give the weed the status of invasive alien species. 


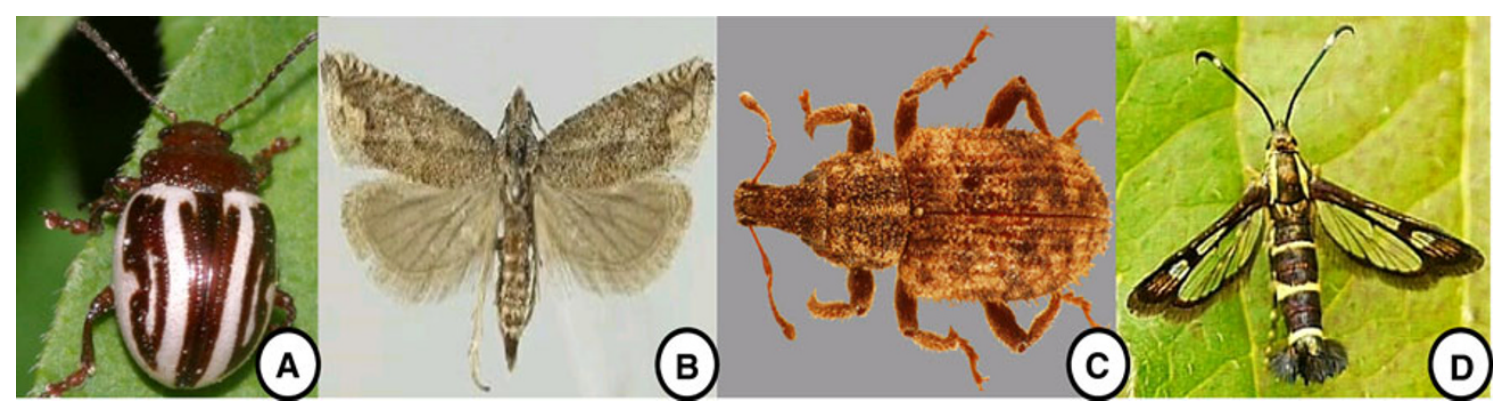

Fig. 3 Biocontrol agents of P. hysterophorus (a) Zygogramma bicolorata (b) Epiblema strenuana (c) Listronotus setosipennis and (d) Carmenta ithacae

\section{Disposal and eradication of $\boldsymbol{P}$. hysterophorus weeds}

Parthenium hysterophorus has multiple harmful aspects and no particular use. Its eradication is a major challenge to government, primarily because of its epidemic proliferation and strong reproductive potential, apart from its wide ecological range. Several physical and chemical methods used in the past to eliminate this weed have proved ineffective, expensive and not eco-friendly. The biomass of this plant is not put to any use and disposed along the roadsides, agricultural fields and railway tracks after uprooting. Further, these weeds are burnt in order to prevent various ailments induced by its toxic sesquiterpene lactone. However, burning of $P$. hysterophorus residues is not a recommended practice as it deteriorates the soil quality by rendering it more alkaline and deficient in organic matter (Singh et al. 2003). Tamado and Milberg (2004) conducted experiments to compare the effect of hand hoeing and applying herbicide (2,4-D) on growth of this weed and its effect on yield of sorghum in small holder farming systems in Ethiopia. Hoeing proved to be more efficient than the use of chemical herbicide.

\section{Biological control of $\boldsymbol{P}$. hysterophorus weeds}

Dhileepan (2003a, b) studied the effectiveness of leaffeeding beetle Zygogramma bicolorata (Fig. 3), stemgalling moth Epiblema strenuana and stem-boring weevil Listronotus setosipennis introduced against P. hysterophorus in Australia. The moth Carmenta ithacae and leafrust Puccinia melampodi were released to eliminate this weed, but little success has been attained in this regard as the weed has great regenerative potential and moreover the insect consumes only the foliage of the weed which stimulates further leafy proliferation (Dhileepan and Strathie 2009). The flowers and seeds, which are the main source of its dissemination, remain unaffected.

Eucalyptus, a native of Australia, is a known allelopathic tree that exerts its toxicity through leachates and volatile terpenes on adjoining vegetation/agricultural crops. The volatile terpenes present in leaves of eucalyptus emanate in the form of vapours into the surroundings. The vapours get adsorbed to soil, curbing the seed germination and reducing the chlorophyll content as well as cellular respiration. The oil vapours increase water loss leading to wilting. Eucalyptus oils may be used as natural herbicides for the biocontrol of $P$. hysterophorus owing to its allelochemicals (Kohli et al. 1998). Cassia sericea has the ability to overgrow $P$. hysterophorus in North-East India. Also marigold (Tagetes erecta) is reported to suppress $P$. hysterophorus growth in field trials (Lakshmi and Srinivas 2007).The control agents for the weed P. hysterophorus are listed in Tables 1, 2.

\section{Exploring future scopes of $\boldsymbol{P}$. hysterophorus}

Pink Morning Glory (Ipomoea carnea) and Spanish Flag Lantana camara are crucial examples regarding management of $P$. hysterophorus. Ipomoea carnea was introduced in India as green manure crop but later it posed a problem. But now, this weed has been discovered to possess many uses.

Ganesh et al. (2008) produced methane-rich gas from solid-feed anaerobic digestion of I. carnea. Patel et al.

Table 1 Harmful effects of $P$. hysterophorus

\begin{tabular}{ll}
\hline Harmful effects & Reference \\
\hline Reducing pasture productivity & Evans (1997) \\
Allelopathy, destroying agroecosystems & Singh et al. (2003) \\
$\begin{array}{l}\text { Allergenic respiratory reactions and allergic } \\
\text { contact }\end{array}$ & Gunaseelan (1987) \\
Dermatitis in humans and livestock & Morin et al. (2009) \\
$\begin{array}{ll}\text { Black spots, blisters around eyes, burning, rings } \\
\text { and blisters over skin, asthma diarrhoea, }\end{array}$ & $\begin{array}{l}\text { Maishi et al. (1998) } \\
\text { severe papular erythematous eruptions, }\end{array}$ \\
$\begin{array}{l}\text { breathlessness and choking } \\
\text { Biodiversity loss }\end{array}$ & Srinivas (2007) \\
\hline
\end{tabular}


Table 2 Biological control of Parthenium hysterophorus

\begin{tabular}{ll}
\hline Biocontrol agent of the weed & Reference \\
\hline Leaf-feeding beetle Zygogramma bicolorata & Dhileepan (2003a, b) \\
Stem-galling moth Epiblema strenuana & \\
Stem-boring weevil Listronotus setosipennis & \\
Moth Carmenta ithacae & Dhileepan and Strathie \\
Leaf-rust Puccinia melampodi & $(2009)$ \\
Fungus Puccinia abrupta var. partheniicola & Fauzi et al. (1999) \\
urediniospores & \\
Fungus Alternaria spp., Fusarium spp., & Lakshmi and Srinivas \\
Rhizoctonia solani,Colletotrichum capsici & $(2007)$ \\
Cassia sericea and Tagetes erecta & Lakshmi and Srinivas \\
& (2007) \\
Eucalyptus oils & Kohli et al. (1998) \\
Flumioxazin, 2,4-D & Grichar (2006) \\
\hline
\end{tabular}

(2010) reported that a novel chitinase enzyme with potential use in agriculture, industry, environmental protection and chito-oligosaccharide production can be purified from the latex of I. carnea. Similarly, L. camara which was once brought to India as an ornamental plant encroaches on agricultural land and reduces the carrying capacity of pastures. Two novel triterpenoids have been isolated from the roots of L. camara L. Its leaves have yielded an essential oil which is rich in sesquiterpenes, and a hepatoprotective compound oleanolic acid is isolated from the roots (Misra and Laatsch 2000). Methanolic extract of $L$. camara leaves exhibit antiulcerogenic activity on gastric and duodenal ulcers in experimental rats (Sathish et al. 2011). It contains high amount of holocellulose and can serve as a low-cost feedstock for bioethanol production (Kuhad et al. 2010). The same strategy can be adopted for dealing with $P$. hysterophorus. Some future prospects envisioned for $P$. hysterophorus are presented in Table 3.

\section{Health benefits of $P$. hysterophorus}

The decoction of $P$. hysterophorus has been used in traditional medicine to treat fever, diarrhoea, neurologic disorders, urinary tract infections, dysentery, malaria and as emmenagogue (Surib-Fakim et al. 1996). Ethnobotanically, it is used by some tribes as remedy for inflammation, eczema, skin rashes, herpes, rheumatic pain, cold, heart trouble and gynaecological ailments. Parthenium hysterophorus has been found to be pharmacologically active as analgesic in muscular rheumatism, therapeutic for neuralgia and as vermifuge (Maishi et al. 1998). This weed is also reported as promising remedy against hepatic amoebiasis. Parthenin, the major constituent of the plant, exhibits significant medicinal attributes including anticancer property (Venkataiah et al. 2003). The methanol extract of the flowers showed significant antitumour activity and parthenin exhibited cytotoxic properties against $\mathrm{T}$ cell
Table 3 Possible utilization of P. hysterophorus

\begin{tabular}{|c|c|}
\hline Uses & Reference \\
\hline Removal of heavy metals from environment to sequester $\mathrm{Cd}$ (II) ions from soil & Ajmal et al. (2006) \\
\hline Sequestration of $\mathrm{Ni}(\mathrm{II})$ from aqueous solution onto activated carbon & Lata et al. (2008) \\
\hline Eradication of salvinia and water hyacinth from water bodies & Pandey (1994) \\
\hline $\begin{array}{l}\text { Carbonized parthenium can be used for removal of dyes, heavy metals, nitrates } \\
\text { and phenols }\end{array}$ & $\begin{array}{l}\text { Rajeshwari and Subburam } \\
\text { (2002) }\end{array}$ \\
\hline PAC has excellent cresol adsorptive characteristic & Singh et al. (2008) \\
\hline Additive with cattle manure in biogas production & Gunaseelan (1987) \\
\hline Ovicidal, anti-fleedant, and nematocidal activity & Datta and Saxena (2001) \\
\hline P. hysterophorus can be used as low-cost substrate for xylanase production & Dwivedi et al. (2009) \\
\hline As compost; green manure for maize and mungbean production & $\begin{array}{l}\text { Kishor et al. (2010); } \\
\text { Javaid (2008) }\end{array}$ \\
\hline Silver nanoparticles formation for biomedical uses & Parashar et al. (2009) \\
\hline Parthenin exhibits significant anticancer property & Das et al. (2007) \\
\hline $\begin{array}{l}\text { Folk remedy against skin diseases, ulcerated sores, facial neuralgia, fever and } \\
\text { anaemia }\end{array}$ & Venkataiah et al. (2003) \\
\hline As analgesic in muscular rheumatism and vermifuge to eliminate helminths & Maishi et al. (1998) \\
\hline $\begin{array}{l}\text { Treat inflammation, eczema, skin rashes, herpes, rheumatic pain, cold heart } \\
\text { trouble and as a remedy for female ailments }\end{array}$ & Maishi et al. (1998) \\
\hline $\begin{array}{l}\text { Treat fever, diarrhoea, neurologic disorders, urinary infections, dysentery, } \\
\text { malaria and as emmenagogue }\end{array}$ & Surib-Fakim et al. (1996) \\
\hline Flea-repellent for ridding dogs & Maishi et al. (1998) \\
\hline Animal feed due to high potash, oxalic acids and protein & Mane et al. (1986) \\
\hline
\end{tabular}


leukaemia, HL-60 and Hela cancer cell lines (Das et al. 2007). Previously, Ramos et al. (2002) had established the antitumour potential of $P$. hysterophorus extracts in vitro and in vivo with positive results in terms of tumour size reduction and overall survival of cell lines. Aqueous extract of $P$. hysterophorus has hypoglycaemic activity against alloxan-induced diabetic rats (Patel et al. 2008). So, flower extract of this weed can be used for developing drug for diabetes mellitus.

Parashar et al. (2009) reported the synthesis of silver nanoparticles by reducing silver ions present in the aqueous solution of silver nitrate complex using the extract of $P$. hysterophorus. This discovery can promote this noxious plant into a valuable weed for nanotechnology-based industries in future. Applications of such eco-friendly nanoparticles in bactericidal, wound healing and other medical and electronic applications makes this method potentially exciting for the large-scale synthesis of other nanomaterials.

\section{Role of $\boldsymbol{P}$. hysterophorus in enhancement of crop productivity}

Allelopathy can be used to increase crop production at minimal expenses and to diminish the current reliance on synthetic agrochemicals that degrade the environmental quality. The allelochemicals can be exploited as herbicides, insecticides, nematicides, fungicides and growth regulator. Pesticidal potential has been established in terms of ovicidal and anti-fleedant effects (Datta and Saxena 2001). The allelochemicals also provide defence against herbivorous predators.

Kishor et al. (2010) prepared compost of P. hysterophorus in 14 weeks and assessed its manure value. Compost from this weed on application in soil enhanced its moisture level more than nitrogen, phosphorus and potassium (NPK) alone. Anaerobic digestion of parthenium dried solids biodegrades the plant growth and conserves the NPK content. This can be applied as organic manure (Gunaseelan 1998). Javaid (2008) used P. hysterophorus weed as green manure for maize and mung bean production. The highest root and shoot biomass in maize was obtained in 3\% green manure treatment, which was significantly greater than that obtained in the control and equivalent to that obtained in the NPK fertilizer treatments.

The effect of $P$. hysterophorus green manure and EM (effective microorganisms), a biofertilizer, on wheat (Triticum aestivum L.) cultivation was studied. Highest root biomass was recorded in $3 \%$ green manure-amended treatment. Spike length, number of grains per spike and grain yield gradually increased by increasing the quantity of green manure. There was $43-253 \%$ increase in grain yield over control due to various green manure treatments as compared with $96 \%$ increase due to NPK fertilizers over control (Javaid and Shah 2010). Parthenium hysterophorus being rich in $\mathrm{N}, \mathrm{P}, \mathrm{K}, \mathrm{Ca}, \mathrm{Mg}$ and chlorophyll content is ideally suited for composting. Ordinary $P$. hysterophorus compost cannot sufficiently reduce the allelopathic effects of high levels of parthenin and phenolics, which impede the early growth, development and dry matter yield of both monocot and dicot plants. For maximum exploitation of the nutrient contents of $P$. hysterophorus, without incurring the ill effects of phenolics, millipede Harphaphe haydenianamediated novel composting procedure was tried. This milli-compost (MC) was more effective than ordinary parthenium compost (OPC) (Apurva et al. 2010). So, if tapped properly, this weed can contribute to agronomic processes.

\section{Bioremediation of heavy metals and dyes by $P$. hysterophorus}

Environmental pollution with heavy metals has become a global phenomenon. Nickel (II) is present in the effluents of silver refineries, electroplating, zinc base casting and storage battery industries. At higher concentrations, nickel causes cancer of lungs, nose and bone. Costeffective alternative technologies or absorbents are needed for the treatment of metal-contaminted wastewaters especially in developing countries like India. Lata et al. (2008) studied the adsorption capacity of $P$. hysterophorus for the removal of nickel from aqueous solution by varying parameters such as agitation time, $\mathrm{Ni}(\mathrm{II})$ concentration, adsorbent dose and $\mathrm{pH}$. The dried biomass of $P$. hysterophorus is used for carbon preparation by mixing it with concentrated sulphuric acid (1:1.5 w/v ratio) and keeping it at $120^{\circ} \mathrm{C}$ for $24 \mathrm{~h}$, followed by washing and drying. This sulphuric acid-treated carbonized Parthenium (SWC) could be an effective, easily available and low-cost adsorbent for the removal of $\mathrm{Ni}$ (II) from dilute aqueous solution.

Cadmium (Cd) is widely used in electroplating, plastic manufacturing, metallurgical processes and industries of pigments and $\mathrm{Cd} / \mathrm{Ni}$ batteries. However, it is extremely toxic even in low dosages and responsible for causing renal disorder, high blood pressure, bone deformity and destruction of RBCs. Because of bioaccumulation, Cd (II) is considered as a priority pollutant by the US Environmental Protection Agency. Ajmal et al. (2006) studied the efficiency of dried powder of $P$. hysterophorus as an adsorbent for removing $\mathrm{Cd}(\mathrm{II})$ from waste water. Batch process was employed for adsorption of $\mathrm{Cd}$ (II) ions by dried and crushed mass of $P$. hysterophorus. Atomic absorption spectrophotometry (AAS) of the filtrate showed 
that $P$. hysterophorus is an effective adsorbent over a wide range of initial $\mathrm{Cd}(\mathrm{II})$ concentration. The maximum adsorption of $\mathrm{Cd}(\mathrm{II})$ ions in the $\mathrm{pH}$ range 3-4 was $99.7 \%$. The desorption studies showed $82 \%$ recovery of $\mathrm{Cd}(\mathrm{II})$ from the adsorbent, when $0.1 \mathrm{M} \mathrm{HCl}$ solution was used as effluent.

Cresol, a phenol derivative, is found in effluents of petrochemical, oil and metal refineries, chemical and glass fibre manufacturing, ceramic and steel plants, phenolic resin manufacturing industries, etc. This toxic effluent is known to cause stomach tumours, corrode the eyes, skin and respiratory tracts and affect the central nervous system, cardiovascular system, lungs, kidney and liver, even leading to unconsciousness and death. Activated carbon prepared from $P$. hysterophorous by chemical activation using concentrated $\mathrm{H}_{2} \mathrm{SO}_{4}$ is an effective adsorbent material. In order to test the adsorbent efficacy of parthenium-based activated carbon (PAC), it is compared with commercial grade activated carbon (AC). PAC is found to be as good as $\mathrm{AC}$ for removal of p-cresol up to a concentration of $500 \mathrm{mg} / \mathrm{l}$ in aqueous solution. $\mathrm{AC}$ is an expensive activated carbon and so regeneration is essential. In contrast to this, PAC is inexpensive, easily available and does not need regeneration and thus promises sustainable utilization in p-cresol removal from industrial wastewater (Singh et al. 2008).

The discharge of coloured waste into streams affects their aesthetic nature, reduces photosynthesis and renders aquatic bodies toxic due to the metals and chlorides in it. Adsorbents prepared from $P$. hysterophorus are tested to remove methylene blue from an aqueous solution in a batch reactor. Dye adsorption capacity of sulphuric acid-treated parthenium (SWC) and phosphoric acid-treated parthenium (PWC) is compared with that of commercially available activated carbon (AC). Maximum dye is sequestered by AC; however, PWC and SWC also showed significant results and can be considered as potential adsorbents for methylene blue removal from dilute aqueous solutions (Lata et al. 2007). Going by these promising findings, this weed can be exploited for industrial pollution control.

\section{Eradication of weeds by $P$. hysterophorus}

Salvinia (Salvinia molesta Mitchell), water lettuce (Pistia stratiotes) and water hyacinth (Eichhornia crassipes) choke off water bodies suffocating aquatic creatures. Pandey (1994) studied the effect of dry P. hysterophorus L. leaf powder on these menacing weeds. The treatment caused wilting and desiccation of above-water parts of these floating plants. With the increasing concentration of $P$. hysterophorus extracts, the seed germination and growth of lovegrass (Eragrostis) decreased significantly (Tefera 2002).

\section{P. hysterophorus as substrate for enzyme production}

Xylanases are hydrolytic enzymes that cleave xylans. The end products of xylan degradation have industrial applications for biofuel, artificial sweetener, animal feed production, baking and textile industry, clarification of fruit juices and coffee extraction. Besides, there has been an increasing interest in using xylanases for ecofriendly bleaching of pulp in paper industries. The potential of $P$. hysterophorus as low-cost raw material for xylanase production was studied by Dwivedi et al. (2009). They investigated xylanase production from a mutant of Penicillium oxalicum in submerged fermentation. Considerably higher level of the enzyme production in medium containing $P$. hysterophorus confirms the feasibility of using this cheap resource as an alternative carbon source to save costs of the enzyme production process (Dwivedi et al. 2009).

\section{$P$. hysterophorus as additive with cattle manure in biogas production}

In the wake of oil crisis, energy generation from biowastes by anaerobic digestion has attracted immense attention. Energy crops are likely to be future sources of digester feed stocks for methane generation. Parthenium hysterophorus was mixed with cattle manure at a $10 \%$ level and allowed to digest anaerobically at room temperature in 3-1 batch digesters. The chemical changes during the course of digestion and the effect of digested slurry (inoculum) on biogas production were investigated and significant increase in methane content was achieved. The methane content of the gas varied between 60 and $70 \%$ (Gunaseelan 1987). Parthenium hysterophorus should be seriously considered as a substrate for the production of biogas in India via anaerobic digestion, considering the abundance of this weed and large quantity of livestock.

\section{$P$. hysterophorus for welfare of livestock}

Parthenium hysterophorus can be used as a flea-repellent for dogs (Maishi et al. 1998). This weed is a valuable source of potash, oxalic acids and high-quality protein (HQP) which can be used in animal feed (Mane et al. 1986). 


\section{Discussion}

Mechanical, chemical and biological control strategies have been proved futile individually to curb proliferation of $P$. hysterophorus. So, integrated approaches are warranted to restrict the invasion of this weed. To address this problem, public awareness has to be developed and participatory approach to control the invasive weeds should be adopted.

There is the need to encourage the research on the utilization potential of this weed and to evaluate its efficacy on field trials. The target of "control through utilization" can be achieved through joint efforts of researchers, farmers, governmental and non-governmental agencies. The discovery of the uses of this weed also could pave the way for indirect eradication of the weed. At present, although $P$. hysterophorus is considered a weed, its new uses are coming to the forefront. Nanomedicine, biopecticide, green manure potential, agent for bioremediation of toxic metals and dyes, herbicide, cheap substrate for enzyme production and source of biogas are some of the recently discovered implications of $P$. hysterophorus.

This weed is available in four continents in abundance. Their industrial processing costs are low and devoid of any environmental hazards. The increased utilization of $P$. hysterophorus biomass as energy source and raw materials is necessary in the long term, as fossil fuels are limited. Similarly, its use as manure and pesticide can be appreciated in the wake of the problems posed by chemicals. Isolation and chemical investigation of the compounds in $P$. hysterophorus are required to decipher their properties and predict their applications. In this regard, it is touted to become a boon for the human beings, animals and crops in near future.

Acknowledgments The author acknowledges the internet website http://www.wikipedia.org/ for providing with the figures.

Open Access This article is distributed under the terms of the Creative Commons Attribution License which permits any use, distribution, and reproduction in any medium, provided the original author(s) and source are credited.

\section{References}

Ajmal M, Rao RAK, Ahmad R, Khan MA (2006) Adsorption studies on Parthenium hysterophorous weed: removal and recovery of Cd(II) from wastewater. J Haz Mat B 135:242-248

Akhtar N, Satyam A, Anand V, Verma KK, Khatri R, Sharma A (2010) Dysregulation of $T_{H}$ type cytokines in the patients of Parthenium induced contact dermatitis. Clin Chimica Acta 411:2024-2028

Akter A, Zuberi MI (2009) Invasive alien species in Northern Bangladesh: identification, inventory and impacts. Int J Biodivers Conserv 15:129-134
Apurva P, Sinha SK, Thakur PC (2010) Composting an obnoxious weed, Parthenium hysterophorus L., with the help of a millipede, Harpaphe haydeniana. Asian J Exp Biol Sci 1:337-343

Belz RG, Reinhardt CF, Foxcroft LC, Hurle K (2007) Residue allelopathy in Parthenium hysterophorus L.-does parthenin play a leading role? Crop Prot 26:237-245

Chhabra BR, Kohli JC, Dhillon RS (1999) Three ambrosanolides from Parthenium hysterophorus. Phytochemistry 52:1331-1334

Das B, Reddy VS, Krishnaiah M, Sharma AVS, Ravi Kumar K, Rao JV, Sridhar V (2007) Acetylated pseudoguaianolides from Parthenium hysterophorus and their cytotoxic activity. Phytochemistry 68:2029-2034

Datta S, Saxena DB (2001) Pesticidal properties of parthenin (from Parthenium hysterophorus) and related compounds. Pest Manag Sci 57:95-101

De La Fuente JR, Novara L, Alarcon SR, Diaz OJ, Uriburu ML, Sosa VE (1997) Chemotaxonomy of Parthenium: P. hysterophorus $-P$. glomeratum. Phytochemistry 45:1185-1188

Dhileepan K (2003a) Seasonal variation in the effectiveness of the leaf-feeding beetle Zygogramma bicolorata (Coleoptera: Chrysomelidae) and stem-galling moth Epiblema strenuana (Lepidoptera: Tortricidae) as biocontrol agents on the weed Parthenium hysterophorus (Asteraceae). Bull Entomol Res 93:393-401

Dhileepan K (2003b) Current status of the stem-boring weevil Listronotus setosipennis (Coleoptera: Curculionidae) introduced against the weed Parthenium hysterophorus (Asteraceae) in Australia. Biocontrol Sci Technol 13:3-12

Dhileepan K (2007) Biological control of Parthenium (Parthenium Hysterophorus) in Australian rangeland translates to improved grass production. Weed Sci 55:497-501

Dhileepan K, Strathie L (2009) Parthenium hysterophorus L. (Asteraceae). In: Muniappan R, Reddy DVR, Raman A (eds) Biological control of tropical weeds using arthropods. Cambridge University Press, UK, pp 272-316

Dwivedi P, Vivekanand V, Ganguly R, Singh RP (2009) Parthenium sp. as a plant biomass for the production of alkalitolerant xylanase from mutant Penicillium oxalicum $\mathrm{SAU}_{\mathrm{E}-3.510}$ in submerged fermentation. Biomass Energy 33:581-588

Evans H (1997) Parthenium hysterophorus: a review of its weed status and the possibilities for biological control. Biocontrol News Inf 18:389-398

Fauzi MT, Tomley J, Dart PJ, Ogle HJ, Adkins SW (1999) The Rust Puccinia abrupta var. partheniicola, a potential biocontrol agent of Parthenium weed: environmental requirements for disease progress. Biol Control 14:141-145

Ganesh PS, Sanjeevi R, Gajalakshmi S, Ramasamy EV, Abbasi SA (2008) Recovery of methane-rich gas from solid-feed anaerobic digestion of ipomoea (Ipomoea carnea). Bioresour Technol 99:812-818

Grichar WJ (2006) Weed control and grain sorghum tolerance to flumioxazin. Crop Prot 25:174-177

Gunaseelan VN (1987) Parthenium as an additive with cattle manure in biogas production. Biol Wastes 21:195-202

Gunaseelan VN (1998) Impact of anaerobic digestion of inhibition potential of Parthenium soids. Biomass Bioenergy 14:179-184

Gupta N, Martin BM, Metcalfe DD, Subba Rao PV (1996) Identification of a novel hydroxyproline-rich glycoprotein as the major allergen in Parthenium pollen. J Allergy Clin Immunol 98:903-912

Javaid A (2008) Use of parthenium weed as green manure for maize and mungbean production. Philipp Agric Sci 91(4)

Javaid A, Shah MBM (2010) Growth and yield response of wheat to EM (effective microorganisms) and parthenium green manure. Afr J Biotechnol 9:3373-3381

Kishor P, Ghosh AK, Singh S, Maury BR (2010) Potential use of parthenium (Parthenium hysterophorus L.) in agriculture. Asian J Agric Res 4:220-225 
Kohli RK, Batish DR, Singh HP (1998) Eucalyptus oils for the control of Parthenium (Parthenium hysterophorus L.). Crop Prot 17:119-122

Kuhad RC, Gupta R, Khasa YP, Singh A (2010) Bioethanol production from Lantana camara (red sage): pretreatment, saccharification and fermentation. Bioresour Technol 101:83488354

Kumar M, Kumar S (2010) Effect of Parthenium hysterophorus ash on growth and biomass of Phaseolus mungo. Acad Arena 2(1)

Lakshmi C, Srinivas CR (2007) Parthenium: A wide angle view. Ind J Dermatol Venereol Leprol 73:296-306

Lata H, Garg VK, Gupta RK (2007) Removal of a basic dye from aqueous solution by adsorption using Parthenium hysterophorus: an agricultural waste. Dyes Pigment 74:653-658

Lata H, Garg VK, Gupta RK (2008) Sequestration of nickel from aqueous solution onto activated carbon prepared from Parthenium hysterophorus L. J Haz Mat 157:503-509

Maishi AI, Ali PKS, Chaghtai SA, Khan G (1998) A proving of Parthenium hysterophorus, L. Brit Homoeopath J 87:17-21

Mane JD, Jadav SJ, Ramaiah NA (1986) Production of oxalic acid from dry powder of Parthenium hysterophorus L. J Agric Food Chem 34:989-990

Misra L, Laatsch H (2000) Triterpenoids, essential oil and photooxidative $28 \rightarrow$ 13-lactonization of oleanolic acid from Lantana camara. Phytochemistry 54:969-974

Morin L, Reid AM, Sims-Chilton NM, Buckley YM, Dhileepan K, Hastwell GT, Nordblom TL, Raghu S (2009) Review of approaches to evaluate the effectiveness of weed biological control agents. Biol Control 5:1-15

Narasimban TR, Murthy BSK, Harindramath N, Rao PVS (1984) Characterization of a toxin from Parthenium hysterophorus and its mode of excretion in animals. J Biosci 6:729-738

Oudhia P, Pandey N, Tripathi RS (1999) Allelopathic effects of obnoxious weeds on germination and seedling vigour of hybrid rice. Int Rice Res Notes 24:36

Pandey DK (1994) Inhibition of salvinia (Salvinia molesta Mitchell) by parthenium (Parthenium hysterophorus L.). I. Effect of leaf residue and allelochemicals. J Chem Biol 19:2651-2662

Parashar V, Parashar R, Sharma B, Pandey A (2009) Parthenium leaf extract mediated synthesis of silver nano particles: a novel approach towards weed utilization. Digest J Nanomater Biostruct 4:45-50

Patel VS, Chitra VP, Prasanna L, Krishnaraju V (2008) Hypoglycemic effect of aqueous extract of Parthenium hysterophorus L. in normal and alloxan induced diabetic rats. Ind $\mathrm{J}$ Pharmacol 40:183-185

Patel AK, Singh VK, Yadav RP, Moir AJG, Jagannadham MV (2010) Purification and characterization of a new chitinase from latex of Ipomoea carnea. Proc Biochem 45:675-681

Rajeshwari S, Subburam V (2002) Activated parthenium carbon as an adsorbent for the removal of dyes and heavy metal ions from aqueous solution. Bioresour Technol 85:205-206
Rajkumar EDM, Kumar NVN, Haran NVH, Ram NVS (1988) Antagonistic effect of $P$. hysterophorus on succinate dehydrogenase of sheep liver. J Environ Biol 9:231-237

Ramos A, Rivero R, Victoria MC, Visozo A, Piloto J, Garcia A (2001) Assessment of mutagenicity in Parthenium hysterophorus L. J Ethnopharmacol 77:25-30

Ramos A, Rivero R, Visozo A, Piloto J, Garcia A (2002) Parthenin, a sesquiterpene lactone of Parthenium hysterophorus L. is a high toxicity clastogen. Mut Res 514:19-27

Sathish R, Vyawahare B, Natarajan K (2011) Antiulcerogenic activity of Lantana camara leaves on gastric and duodenal ulcers in experimental rats. J Ethnopharmacol. doi:10.1016/j.jep.2010.11.049

Sharma VK, Sethuraman G, Bhat R (2005) Evolution of clinical pattern of parthenium dermatitis: a study of 74 cases. Contact Dermat 53:84-88

Singh HP, Batish DR, Pandher JK, Kohli RK (2003) Assessment of allelopathic properties of Parthenium hysterophorus residues. Agric Ecosys Environ 9:537-541

Singh RK, Kumar S, Kumar S, Kumar A (2008) Development of parthenium based activated carbon and its utilization for adsorptive removal of p-cresol from aqueous solution. J Haz Mat 155:523-535

Sriramarao P, Prakash O, Metcalfe D, Subba Rao P (1993) The use of murine polyclonal anti-idiotypic antibodies as surrogate allergens in the diagnosis of Parthenium hypersensitivity. J Allergy Clin Immunol 92:567-580

Surib-Fakim A, Swerab MD, Gueho J, Dullo E (1996) Medicinal plants of Rodrigues. Int J Pharmacogn 34:2-14

Tamado T, Milberg P (2004) Control of parthenium (Parthenium hysterophorus) in grain sorghum (Sorghum bicolor) in the smallholder farming system in eastern Ethiopia. Weed Technol 18:100-105

Tefera T (2002) Allelopathic effects of Parthenium hysterophorus extracts on seed germination and seedling growth of Eragrostis tef. J. Agron Crop Sci 188:306-310

Timsina B, Shrestha BB, Rokaya MB, Munzbergova Z (2011) Impact of Parthenium hysterophorus L. invasion on plant species composition and soil properties of grassland communities in Nepal. Flora Morphol Distribution Funct Ecol Plants. doi: 10.1016/j.flora.2010.09.004

Towers GHN, Subbha Rao PV (1992) Impact of the pan-Tropical weed, P. hysteroporus L. on human affairs. In: Richardson RG (ed) Proceedings of the first international weed control congress, Melbourne, Australia, Weed science society of Victoria, pp 134-138

Venkataiah B, Ramesh C, Ravindranath N, Das B (2003) Charminarone, a seco-pseudoguaianolide from Parthenium hysterophorus. Phytochemistry 63:383-386

Yadav N, Saha P, Jabeen S, Kumara S, Kumara S, Verma SK, Raipat BS, Sinha MP (2010) Effect of methanolic extract of $P$. hysterophorus $\mathrm{L}$. on haematological parameters in wistar albino rat. Bioscan 2:357-363 